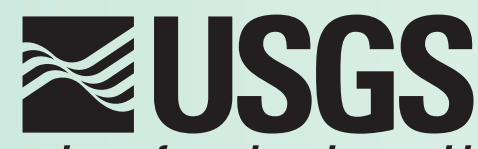

science for a changing world

\title{
Understanding Metal Pathways in Mineralized Ecosystems
}

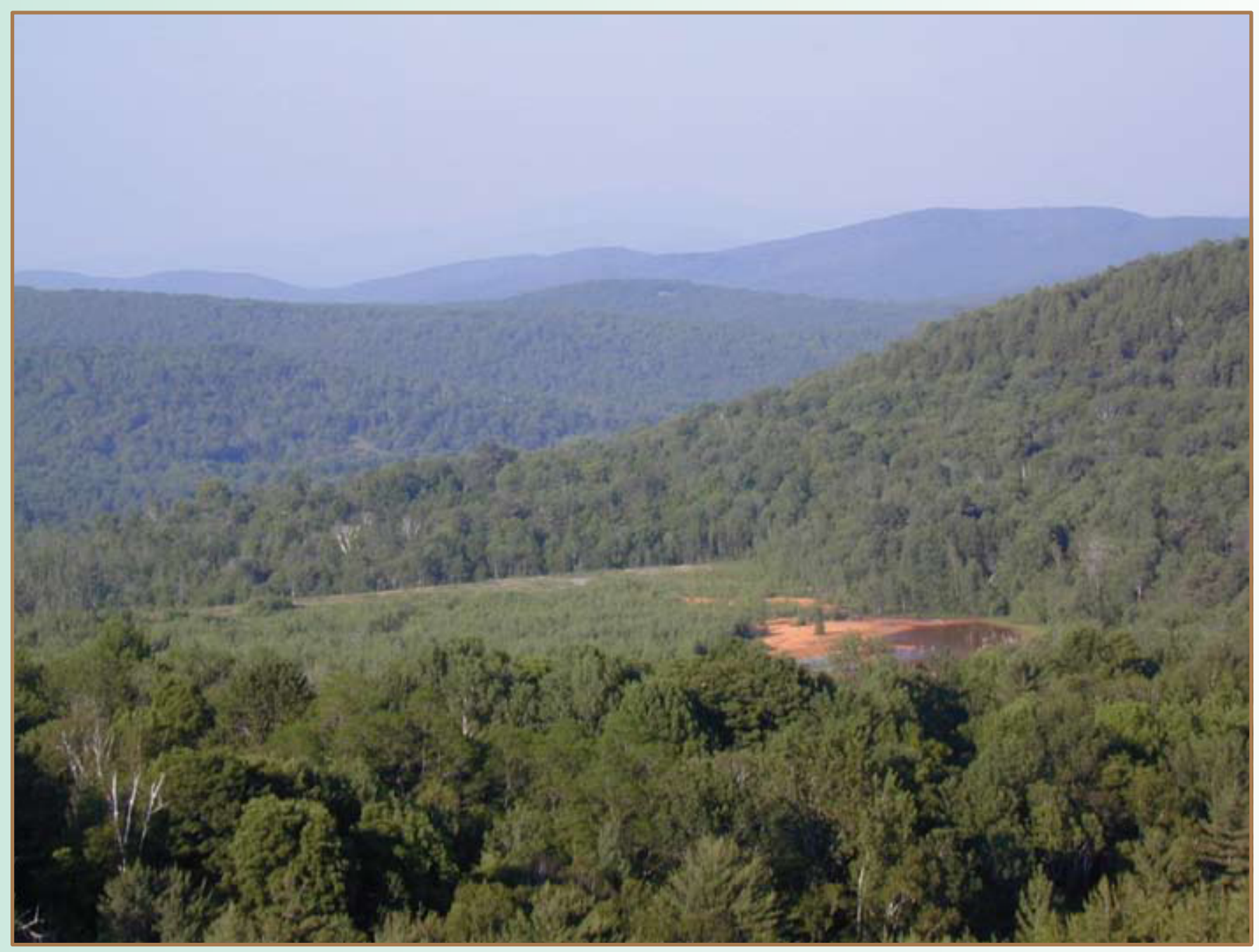

Circular 1317

U.S. Department of the Interior

U.S. Geological Survey 


\section{Understanding Metal Pathways in Mineralized Ecosystems}

By Laurie S. Balistrieri, Andrea L. Foster, Larry P. Gough, Floyd Gray, James J. Rytuba, and Lisa L. Stillings

The USGS Pathways of Metal Transfer from Mineralized Sources to Bioreceptors Project studied the physical and biogeochemical processes that influence the distribution, concentration, and bioavailability of potentially toxic metals at historical hard-rock mine sites in the western United States.

Circular 1317

U.S. Department of the Interior

U.S. Geological Survey 


\section{U.S. Department of the Interior DIRK KEMPTHORNE, Secretary}

\section{U.S. Geological Survey Mark D. Myers, Director}

\section{U.S. Geological Survey, Reston, Virginia: 2007}

This report and any updates to it are available online at:

http://pubs.usgs.gov/circ/2007/1317/

For product and ordering information:

World Wide Web: http//www.usgs.gov/pubprod

Telephone: 1-888-ASK-USGS (1-888-275-8747)

For more information on the USGS - the Federal source for science about the Earth, its natural and living resources, natural hazards, and the environment:

World Wide Web: http://www.usgs.gov/

Telephone: 1-888-ASK-USGS (1-888-275-8747)

Any use of trade, product, or firm names in this publication is for descriptive purposes only and does not imply endorsement of the U.S. Government.

Although this report is in the public domain, permission must be secured from the individual copyright owners to reproduce any copyrighted materials contained within this report.

Suggested citation:

Balistrieri, L.S., Foster, A.L., Gough, L.P., Gray, Floyd, Rytuba, J.J., and Stillings, L.L., 2007, Understanding metal pathways in mineralized ecosystems: U.S. Geological Survey Circular 1317, 12 p.

\section{Cataloging-in-publication data are on file with the Library of Congress (http://www.loc.gov/).}

Produced in the Western Region, Menlo Park, California

Manuscript approved for publication, August 9, 2007

Text edited by Peter H. Stauffer

Layout and design by Jeanne S. DiLeo

FRONT COVER

Acidic and metal-enriched mine drainage forms a pond on mine tailings at the historical Elizabeth Copper Mine, South Strafford, Vermont. This mine site was listed on the National Priority List (Superfund) in June 2001. 


\section{Contents}

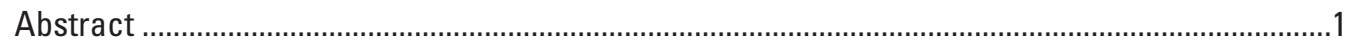

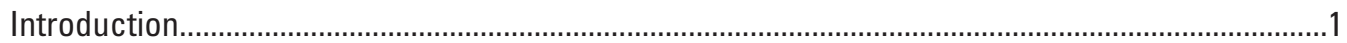

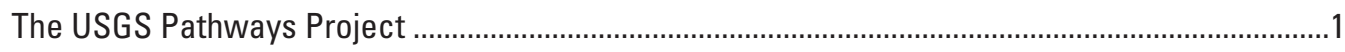

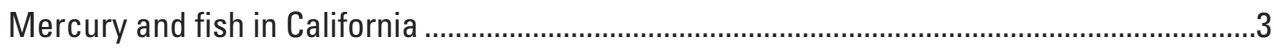

Why was the study done? ............................................................................................

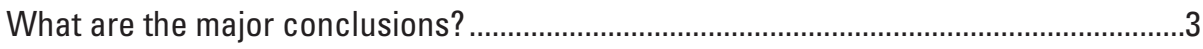

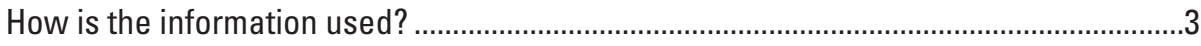

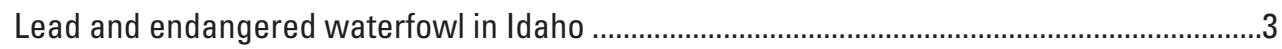

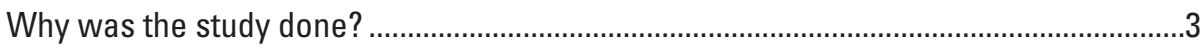

What are the major conclusions? ....................................................................................

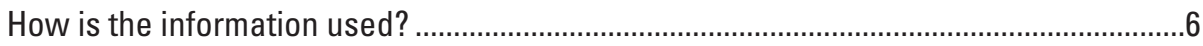

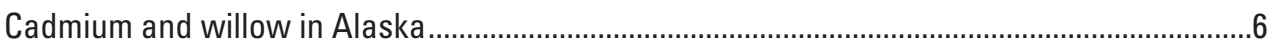

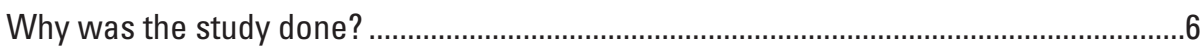

What are the major conclusions? ...............................................................................6

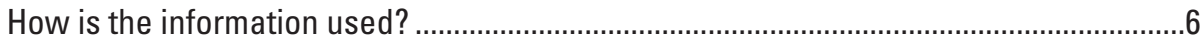

Selenium in wetlands: Case studies in Idaho and Nevada ....................................................6

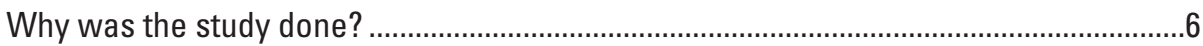

What are the major conclusions? ....................................................................................

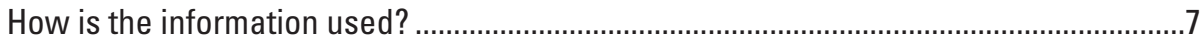

Metal transport and climate in Arizona ....................................................................................

Why was the study done? ...................................................................................................

What are the major conclusions? ........................................................................................

How is the information used? .......................................................................................

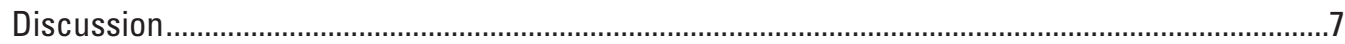

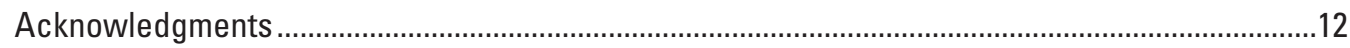

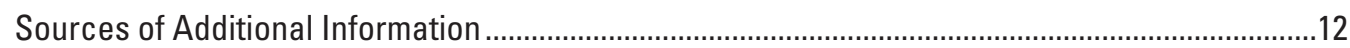





\title{
Understanding Metal Pathways in Mineralized Ecosystems
}

\author{
By Laurie S. Balistrieri, Andrea L. Foster, Larry P. Gough, Floyd Gray, James J. Rytuba, and Lisa L. Stillings
}

\section{Abstract}

Successful management of ecosystems containing historical mine wastes requires understanding of processes that are responsible for the distribution, concentration, and bioavailability of potentially toxic elements. U.S. Geological Survey (USGS) scientists recently completed several investigations at historical mine sites in the western United States. These investigations have improved our understanding of how metals are mobilized from mineralized sources, are transported through the environment, and become available to humans and other biota. The new information is being used by Federal, State, and local agencies that manage and remediate abandoned mine lands.

\section{Introduction}

The mid 1800s marked the beginning of a long and colorful history of mining in the western United States. That history has left a legacy of approximately 11,000 abandoned hard-rock mine sites. At many of these sites, historical mining activities resulted in adverse impacts to the quality of water and sediment and to the health of humans and other biota. Understanding the processes that influence the distribution, concentration, and bioavailability of potentially toxic metallic elements, such as arsenic (As), cadmium (Cd), lead $(\mathrm{Pb})$, mercury $(\mathrm{Hg})$, selenium $(\mathrm{Se})$, and zinc $(\mathrm{Zn})$, is critical for successful management of chronically affected ecosystems where total remediation of environmental problems is not financially or technically possible. Such understanding of processes can be used to identify and target those pathways that have the greatest immediate and long-term impact on the environment and health of biota. It therefore provides the scientific foundation for making decisions, developing strategy, and assessing mitigation and remediation alternatives by local, State, and Federal agencies charged with minimizing the environmental and health impacts of the toxic elements.

\section{The USGS Pathways Project}

The U.S. Geological Survey (USGS) Pathways Project focuses on improving our understanding of the processes that redistribute metals from mineralized sources to human populations and other biological receptors within ecosystems. The major objectives of the Pathways Project are to:

- advance our understanding of the physical, chemical, and biological processes responsible for the cycling of potentially toxic elements in large-scale ecosystems influenced by mineralized deposits and mine wastes,

- identify those pathways that have the greatest chronic or long-term adverse impact to the environment and to the health of biota, and

- develop conceptual and quantitative transport and reaction models that link the concentrations and distributions of elements to specific processes.

To meet these objectives, work within the Pathways Project examines the behavior of various potentially toxic elements in different ecosystems and addresses several interrelated questions:

- How do ecosystem conditions (for example, arid versus wet or vegetated versus non-vegetated) influence the transport and dispersion of elements?

- How does the speciation (specific chemical form) of elements in solution and as particles affect their geochemical mobility and availability to biota?

- How do processes at physical and geochemical boundaries affect element speciation, mobility, and bioavailability?

-What are the relations among different types of microbial communities, the processes that transform elements between various chemical forms, and the availability of elements to biota?

- Can conceptual and quantitative models be developed that link element concentrations and distributions in mineralized ecosystems to specific physical and biogeochemical processes and that help us to understand the possible impacts of natural and anthropogenic changes on element distributions in these systems?

Selected major accomplishments of the USGS Pathways studies that addressed these issues are highlighted in the following sections. 


\section{Metal Pathways in Mineralized Ecosystems}

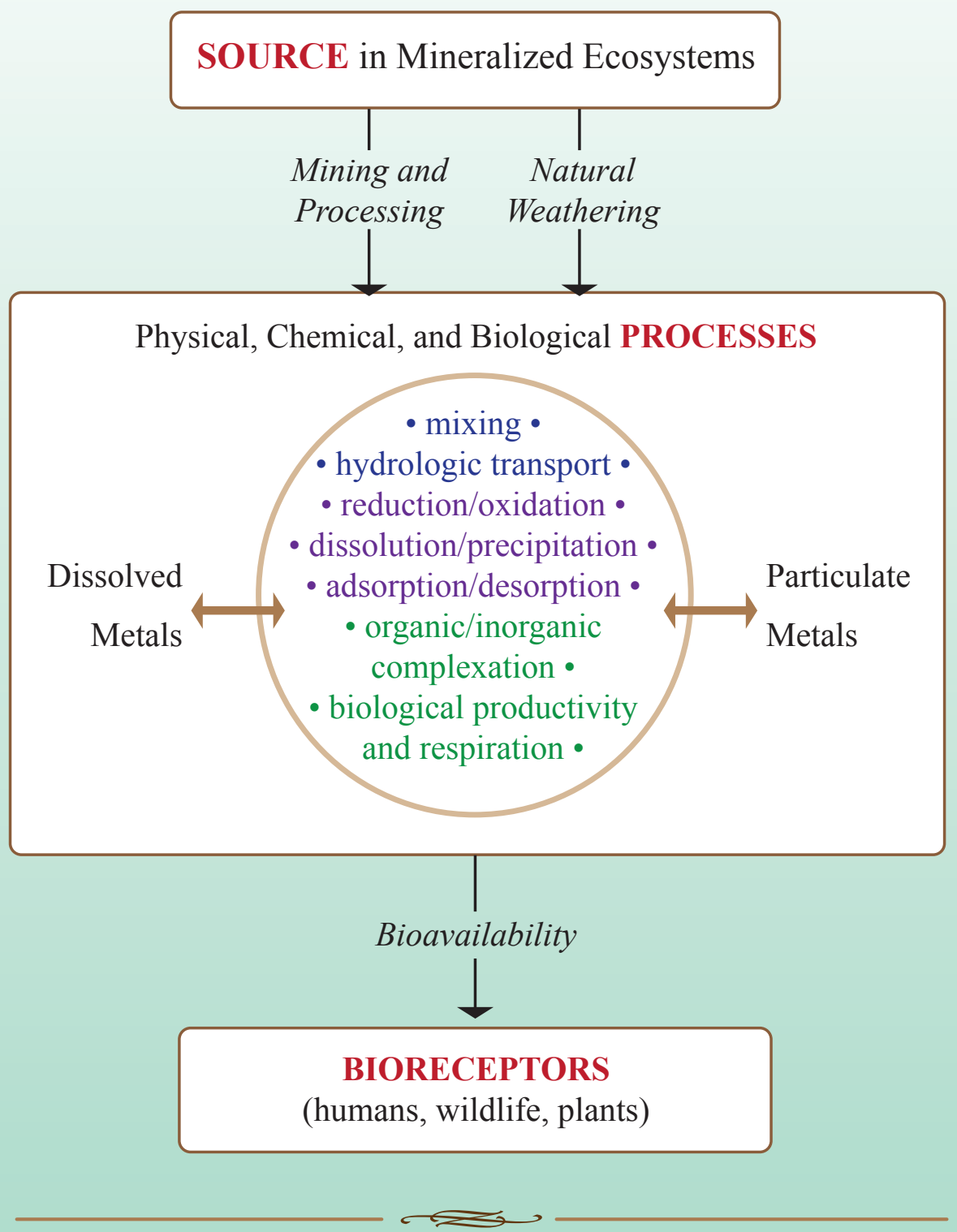

Physical, chemical, and biological processes transport and biogeochemically transform elements as they are redistributed from mineralized sources (ore deposits and mine wastes) to biological organisms. These processes have been the focus of the U.S. Geological Survey (USGS) Pathways Project studies at historical mine sites in the western United States 


\section{Mercury and Fish in California}

\section{Why was the study done?}

Historical placer gold dredging in the floodplains of many rivers in the western United States has modified river geomorphology and impaired the spawning and rearing habitats of salmonid species. In addition, the dredge tailings contain mercury $(\mathrm{Hg})$, an element used in the mining process to concentrate gold. Large-scale river-restoration projects in mining-affected watersheds may mobilize mercury from the tailings and downstream sediment derived from them and consequently lead to increased $\mathrm{Hg}$ levels in fish. Knowledge of the processes that control $\mathrm{Hg}$ cycling in the environment is needed to plan and manage river-restoration programs in order to minimize $\mathrm{Hg}$ release from sediments, chemical transformations due to methylation, and accumulation in fish.

\section{What are the major conclusions?}

- $\mathrm{Hg}$ is concentrated in finer grain-size fractions (silt and clay sizes) of contaminated sediments, with $\mathrm{Hg}$ concentrations as much as 300 times higher than in the bulk material.

- Elemental Hg that was introduced during the gold recovery process has been converted to organicbound phases and mercury sulfide, with only $15-40$ percent remaining as elemental $\mathrm{Hg}$.

- Colloidal (submicrometer size) mercury sulfide is readily leached from contaminated silts and sands by water containing organic acids formed from the degradation of plant material.

- Contaminated sediments associated with dredge tailings, including dredge ponds and constructed wetlands ponds in tailings, typically show moderate to high rates of $\mathrm{Hg}$ methylation. The methylation process results in methyl $\mathrm{Hg}$, which is a more bioavailable form of $\mathrm{Hg}$.

- Sands and silts in dredge tailings may be too contaminated to be used in river-restoration projects, but coarser tailings can be moved and used to improve habitat, if the fine sediment is first removed.

\section{How is the information used?}

Study results have been used by the U.S. Bureau of Reclamation in the Trinity River Restoration Project and by the U.S. Bureau of Land Management and U.S. Bureau of Reclamation in the restoration of lower Clear Creek, California. In the Trinity River area, tailings and contaminated sediments that were removed from open floodplain channels were placed above the 100-year flood level and not vegetated in order to minimize the potential release of $\mathrm{Hg}$. Wetlands, originally planned for areas where contaminated sluice sands and silts were found, were sited elsewhere. At Clear Creek, tailings that are moved or used for gravel injection in floodplain restoration are now routinely evaluated for potential release of $\mathrm{Hg}$ and, if necessary, treated to minimize $\mathrm{Hg}$ release.

\section{Lead and Endangered Waterfowl in Idaho}

\section{Why was the study done?}

A century of historical mining, milling, and smelting of world-class silver $(\mathrm{Ag})$, lead $(\mathrm{Pb})$, and zinc $(\mathrm{Zn})$ deposits, disposal of mill waste into rivers, and periodic natural flooding have resulted in the dispersion of metal-enriched water and sediment throughout the Coeur d'Alene River Basin, northern Idaho. In 1983, the U.S. Environmental Protection Agency (EPA) listed an area of 21 square miles in the heart of the basin as a Superfund site. In 1998 the EPA began applying Superfund requirements to many other areas throughout the basin. Many studies indicate that the contaminated materials pose health risks to humans and other biota in the basin. Understanding how metals cycle through this ecosystem is essential for minimizing those health risks.

Marshes in the lower Coeur d'Alene River valley are prime resting and feeding areas for migratory birds. These marshes, however, are enriched in toxic metals, and waterfowl deaths attributed to $\mathrm{Pb}$ poisoning during feeding have been reported for this area. During certain seasons of the year, reddish-brown material forms along the edge of the river in the lower valley. This material is easily re-suspended and transported downstream; it adheres to plant surfaces after floodwaters recede and may be a potential source of metal uptake during feeding by waterfowl. Investigations therefore examined this material and the processes responsible for its composition and formation.

\section{What are the major conclusions?}

- Relative to water in the Coeur d'Alene River, water that is in the pores of levee-bank sediment along the river is acidic and contains high concentrations of sulfate $\left(\mathrm{SO}_{4}\right)$, calcium $(\mathrm{Ca})$, magnesium $(\mathrm{Mg})$, and metals, including arsenic (As), cadmium (Cd), cobalt $(\mathrm{Co})$, copper $(\mathrm{Cu})$, chromium $(\mathrm{Cr})$, iron $(\mathrm{Fe})$, manganese $(\mathrm{Mn})$, lead $(\mathrm{Pb})$, and zinc $(\mathrm{Zn})$. 


\section{Mitigating the Impact of Toxic Mercury on Fish}

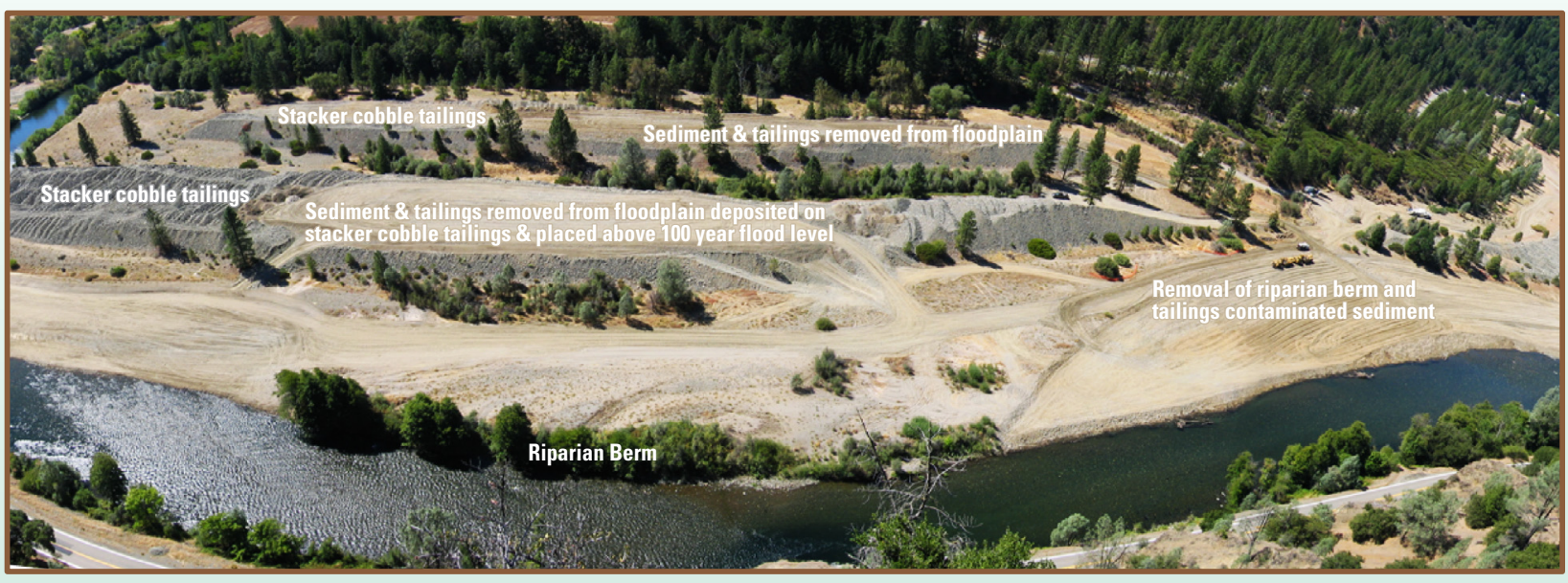

Aerial view of the Trinity River Restoration Project in California. Mercury $(\mathrm{Hg})$ contamination was found to be concentrated in the finer grained sediments; coarse, gravely "stacker tailings" show little contamination. This information helped the responsible agencies mitigate the toxic impact of the mercury on fish as part of the restoration project.
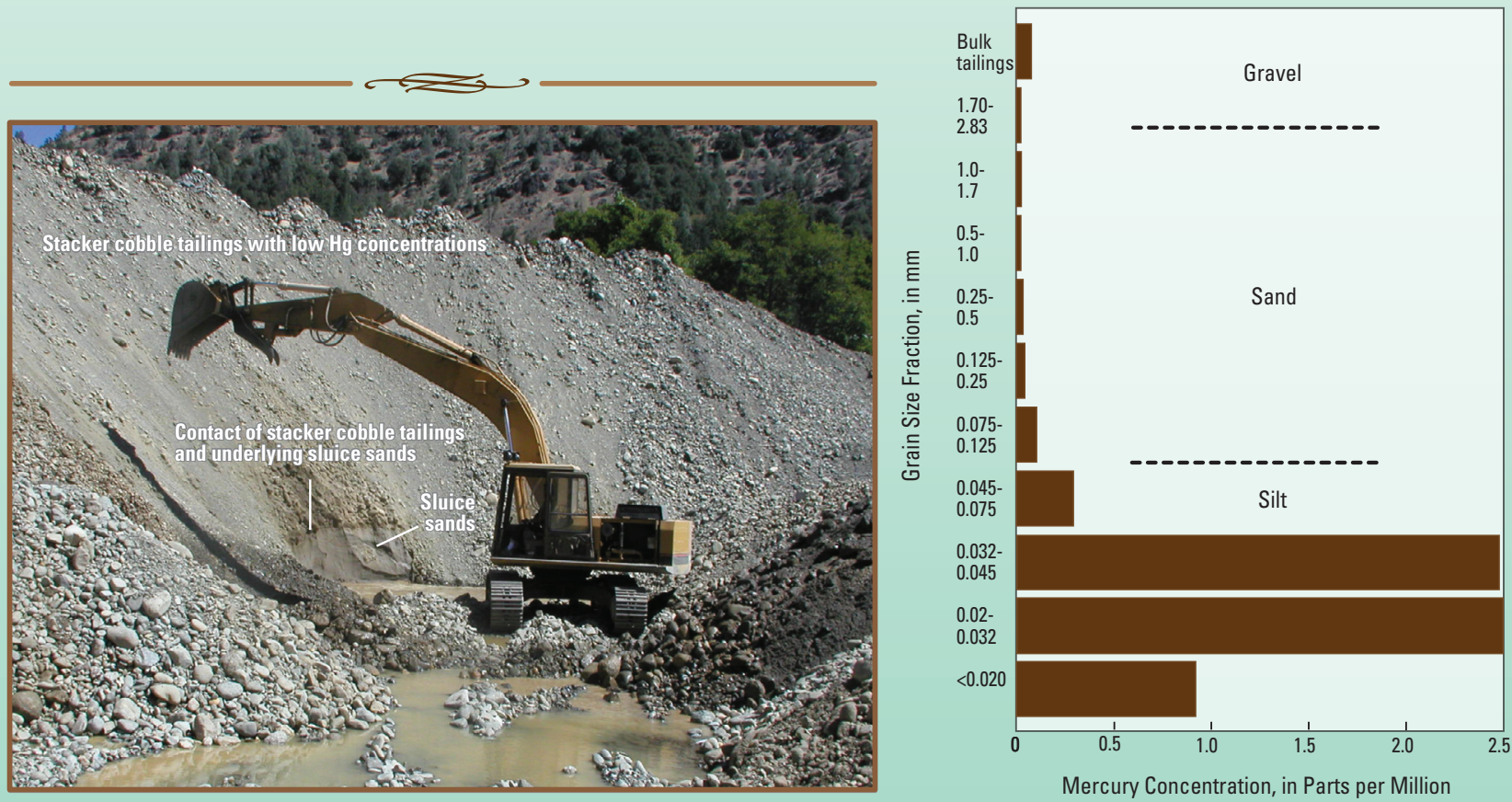

Sluice sands covered by stacker cobble tailings in the Trinity River Restoration Project. The sands and silts in the tailings contain much higher concentrations of mercury $(\mathrm{Hg})$ than the coarser cobbly material. 


\section{Toxic Lead - A Hazard to Waterfowl in the Lower Coeur D'Alene River Valley}

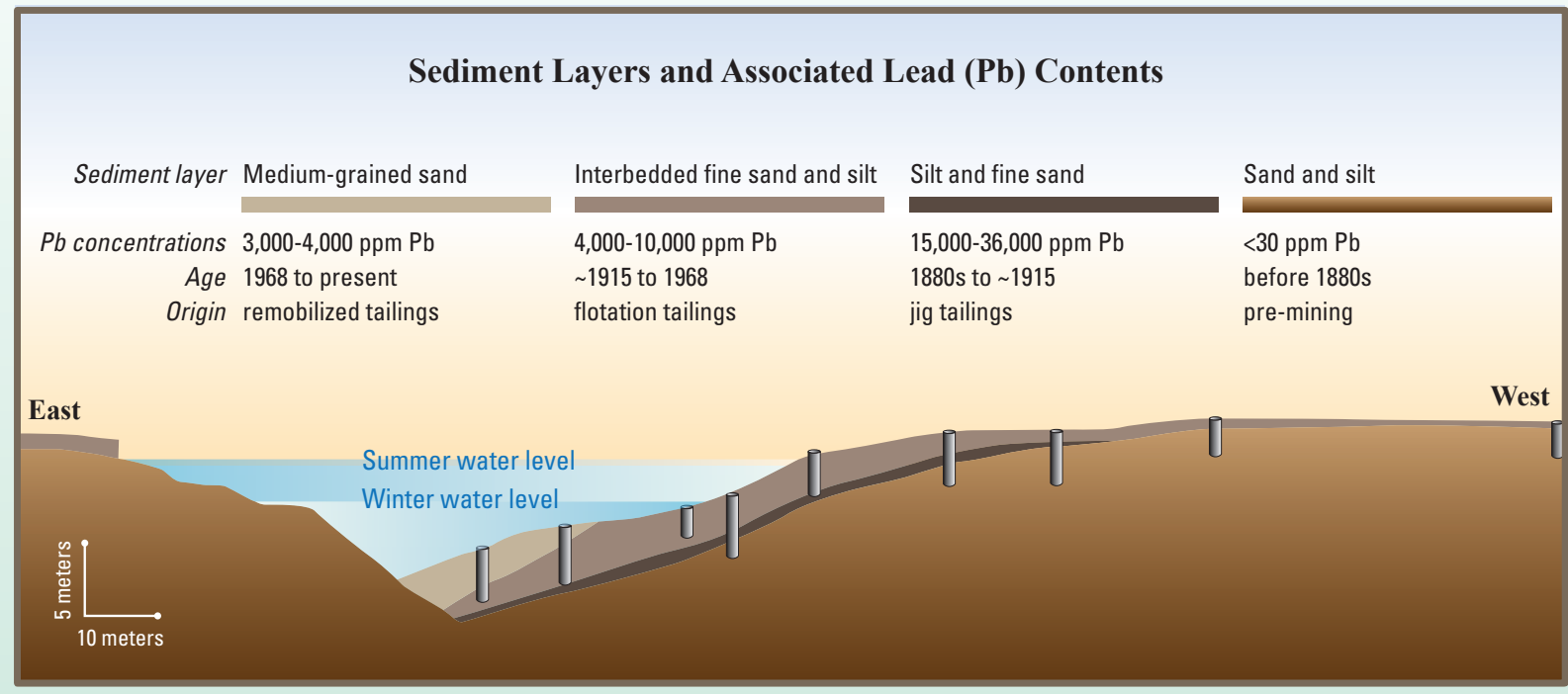

Deaths of migrating waterfowl in the lower Coeur d'Alene River valley have been attributed to poisoning by lead ( $\mathrm{Pb})$ derived from old mine tailings. U.S. Geological Survey (USGS) scientists have found that the $\mathrm{Pb}$ content of different sediment layers downstream from the old mining areas varies-reflecting the history of mining technology. This diagram shows the $\mathrm{Pb}$ content of sediment in cores collected from the floodplain and river channel in the lower Coeur d'Alene River valley. Changes in milling technology (inefficient jigging to more efficient flotation methods) in the mining district helped produce the varying $\mathrm{Pb}$ concentrations with depth. Water levels vary seasonally by about 2 meters. Reddish-brown flocculent material is observed along the river's edge as water levels lower in the fall.

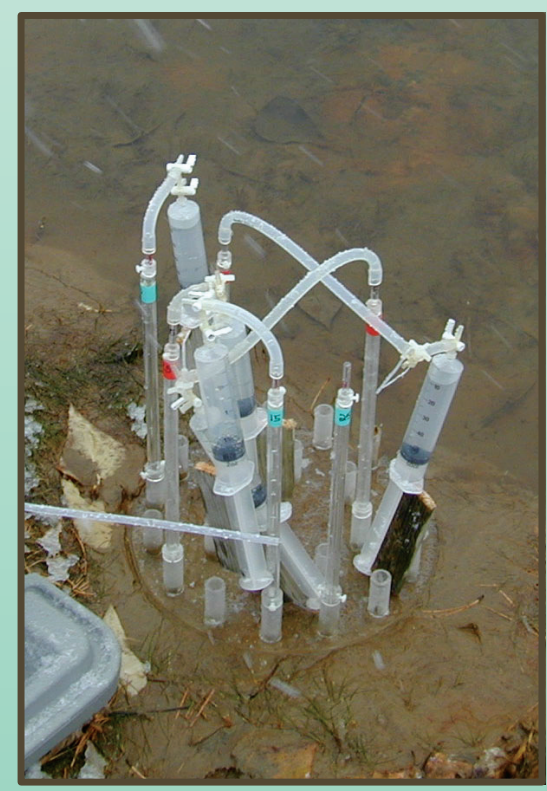

Scientists with the U.S. Geological Survey (USGS) Pathways Project analyzed porewater collected from metal-enriched levee bank sediments along the lower Coeur d'Alene River using a sipper array. Sippers, which are tubes of variable length with fine netting at the bottom, are inserted into the sediment, and porewater is pulled up the tube using a syringe. Reddish-brown flocculent material is seen in the river bottom to the upper right of the sipper array. This reddish-brown material turned out to be an iron oxide that readily adsorbs other metals. 
- The enrichment of elements in porewater is due to oxidation of metal sulfide minerals, dissolution of carbonate minerals, and biologically mediated decomposition of organic matter in bank sediment.

- During annual lowering of water levels in the basin or after floodwaters recede, porewater drains from bank sediment and mixes with the Coeur d'Alene River water. Chemical reactions during the mixing process result in the formation of the metal-enriched, reddish-brown material.

- Chemical analyses and geochemical modeling indicate that the reddish-brown material is an iron oxide, which adsorbs other toxic metals.

\section{How is the information used?}

The results of this study add to the overall understanding of how metals cycle through the Coeur d'Alene River Basin and how they may impact the health of humans and other biological receptors. That knowledge was used by EPA to help develop long-term goals for cleanup and recovery from the effects of historical mining in the basin.

\section{Cadmium and Willow in Alaska}

\section{Why was the study done?}

Previous studies in ecosystems containing mineralized deposits have indicated a direct link between high cadmium (Cd) concentrations in willow leaves and twigs and the occurrence of disease in ptarmigan (grouse) that feed on the willow. Because willow is a preferred source of food for moose in Alaska, investigations of $\mathrm{Cd}$ cycling were conducted in both mineralized and nonmineralized areas throughout Alaska to determine if willow and other plants accumulate $\mathrm{Cd}$ and, if so, to define the geochemical conditions that result in bioaccumulation of $\mathrm{Cd}$. Understanding of $\mathrm{Cd}$ cycling within these ecosystems is important for minimizing adverse impacts to the health of browsing animals, such as moose, and the health of people who hunt those animals.

\section{What are the major conclusions?}

- Willow growing in soils developed from mineralized bedrock accumulates $\mathrm{Cd}$ in concentrations 4 to 10 times higher than willow growing in nonmineralized soil.
- Cd levels in willow are as much as 10 to 100 times greater than those found in other plants, such as green alder, feather moss, and soil lichen, collected from the same area.

- Mineralized areas in Alaska are likely sources for natural occurrences of potentially harmful levels of $\mathrm{Cd}$ in willow, which pose a health threat to browsing animals.

\section{How is the information used?}

Based on our Cd study and to examine links between Cd levels in willow and moose, a database of element concentrations in moose tissue was developed by USGS with assistance from the Alaska Department of Fish and Game and the University of Alaska. Samples of moose kidney from harvested as well as road-kill animals are analyzed and compared with similar moose data from Sweden and Finland and with $\mathrm{Cd}$ data from willow.

\section{Selenium in Wetlands: Case studies in Idaho and Nevada}

\section{Why was the study done?}

Selenium (Se) toxicity, resulting from bioaccumulation in their forage, is a serious threat to livestock, particularly cattle and sheep, in the western United States. High concentrations of $\mathrm{Se}$, released into surface waters during the mining of phosphate deposits in southeastern Idaho and subsequently taken up by plants, are implicated in the deaths of sheep grazing in that area. Wetland soils and plants are known to concentrate Se and thereby promote its entry into the food chain. Understanding how Se cycles through wetland systems will aid in minimizing bioaccumulation by plants and consequent health risks to foraging livestock.

Studies were conducted in two wetlands to assess transport and retention of Se within these systems. One of the study areas is a wetland downstream from the phosphate deposits in Idaho. The other is a wetland in a nature park affected by runoff from Las Vegas, Nevada. These wetlands were compared by evaluating their Se mass balances. A mass balance determines the amount of an element that remains or is retained in the wetland by comparing the amount of the element that enters the wetland with the amount that leaves the wetland. Elements can enter or leave the wetlands by surface streams, by ground water, or through the atmosphere. 


\section{What are the major conclusions?}

- The two wetlands differ in both flow volume and Se concentrations in their inlet and outlet waters. Water entering or leaving the Idaho wetland had lower flows, but higher Se concentrations, than water entering or leaving the Nevada wetland.

- The Idaho wetland retained 611 grams of Se (88 percent of the Se in the inflow) during a five-month period, whereas the Nevada wetland retained 5,800 grams of Se (24 percent of the Se in the inflow) during a four-month period. The amount of Se retained in the wetland likely represents accumulation of Se by plants and wetland sediments, although gains or losses to the wetlands from the ground water and atmosphere were not measured.

\section{How is the information used?}

Land-management agencies are changing their management practices in order to decrease the amount of Se delivered to the studied wetlands. The U.S. Forest Service manages the Idaho wetland; they are now using soil amendments and seed mixtures to immobilize Se within the waste-rock source, hoping to decrease both the concentration of $\mathrm{Se}$ in forage plants in the wetland as well as the concentration of Se in drainage from the waste to the wetland. The Nevada wetland is managed by the Clark County Department of Parks and Recreation; they now use another source of inlet water with lower Se concentrations in order to decrease the amount of $\mathrm{Se}$ entering their wetland.

\section{Metal Transport and Climate in Arizona}

\section{Why was the study done?}

The Patagonia Mountains and southern Santa Rita Mountains in southeastern Arizona were mined for silver $(\mathrm{Ag})$, lead $(\mathrm{Pb})$, copper $(\mathrm{Cu})$, and zinc $(\mathrm{Zn})$ intermittently from the 1600's to the mid-1960's. Our studies examined the transport and chemical behavior of metals in several arid to semiarid watersheds (Harshaw Creek and Alum Gulch drainages) containing these abandoned mine lands. The goal was to evaluate how climate and other ecosystem conditions influence metal cycling in mining-affected ecosystems. Such knowledge is vital for developing robust models that describe potential environmental impacts of mining activity in different climate settings.

\section{What are the major conclusions?}

- Seasonal precipitation and acid mine drainage, which contains metals, such as cadmium $(\mathrm{Cd})$, cobalt $(\mathrm{Co})$, copper $(\mathrm{Cu})$, nickel $(\mathrm{Ni})$, lead $(\mathrm{Pb})$, and zinc $(\mathrm{Zn})$, are the dominant sources of water to the study areas.

- During dry periods, acid rock drainage evaporates and readily soluble metal sulfate salts are deposited on rocks and stream sediment. During storm events, these salts dissolve and release acid and metals back to solution.

- Downstream decreases in acid and metal concentrations after a storm event depend on the ability of the ecosystems to neutralize or buffer the acid produced during salt dissolution and on the volume of water from the storm event. If the buffering capacity of the ecosystem is small, acid and metals are transported far downstream in the dissolved phase. If the buffering capacity of the ecosystem is large, neutralization results in precipitation of aluminum-iron-oxyhydroxide minerals, adsorption of metals, and release of carbon dioxide gas.

\section{How is the information used?}

A major outcome of the research has been an improved understanding of the links among weather conditions, landscape, mineral precipitation and dissolution, and metal transport. The U.S. Forest Service and State of Arizona Environmental Quality Agency are using this information to develop remediation plans for this mining-affected area.

\section{Discussion}

These case studies conducted under the U.S. Geological Survey (USGS) Pathways Project have yielded important new information about the ways in which metals are mobilized from rocks and mining waste, transported and chemically modified, and accumulated in various biota. Many of the metals, including arsenic (As), cadmium (Cd), lead $(\mathrm{Pb})$, mercury $(\mathrm{Hg})$, selenium $(\mathrm{Se})$, and zinc $(\mathrm{Zn})$, are potentially toxic to animals and humans. The results of these studies provide a better understanding of the physical and biogeochemical processes that influence the distribution, concentration, and bioavailability of the metals in mineralized ecosystems, not only in historical mining areas, but also in planning and developing new mines. 


\section{Willows Concentrate Toxic Cadmium in Alaska}

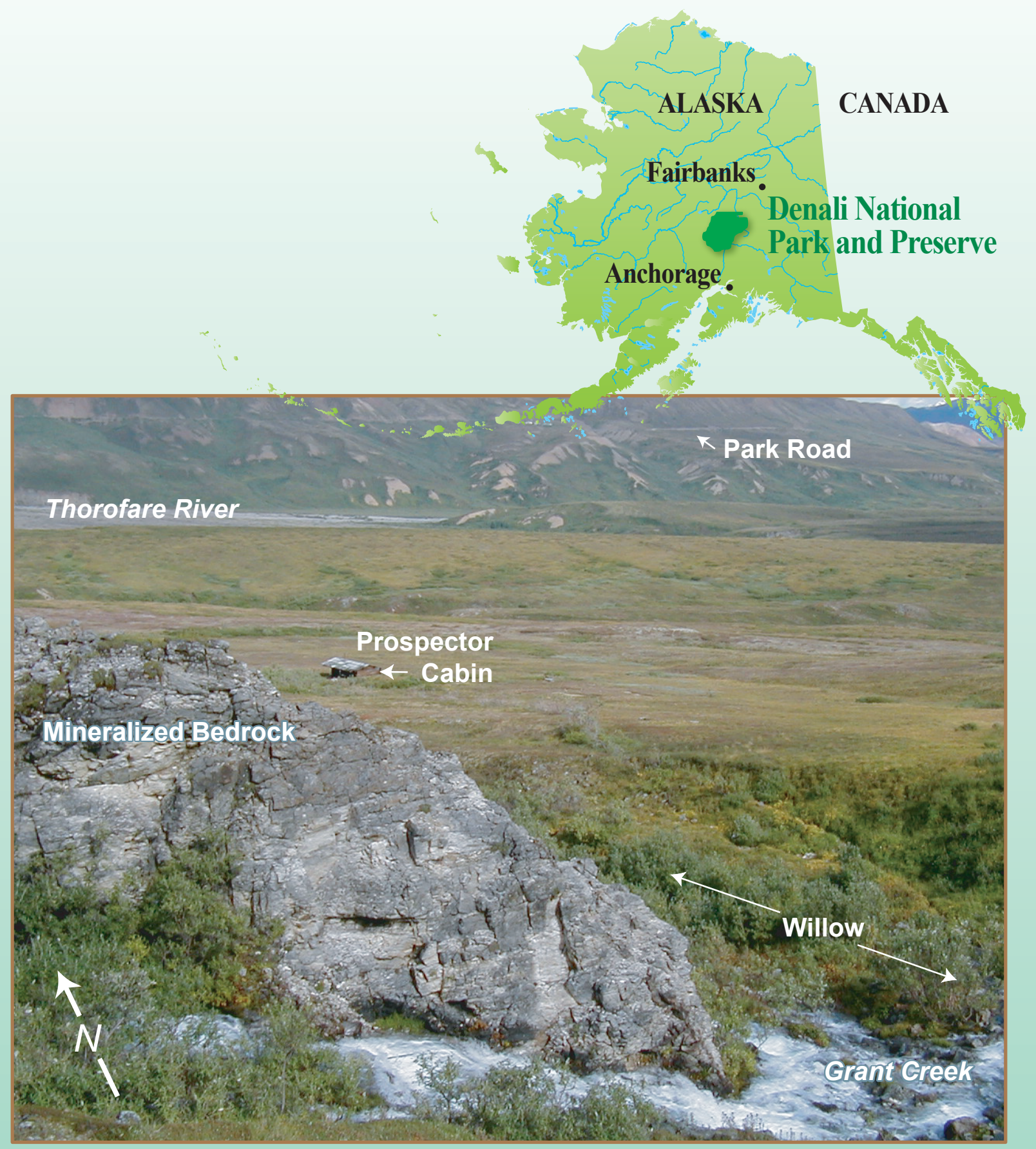

The Mt. Eielson mining district, Denali National Park and Preserve, with Grant Creek and typical mineralized bedrock in the foreground, a historic cabin dating to the days of mineral prospecting in the district in the near background, and the Thorofare River and park road in the far background. This area hosts a number of lead-zinc (Pb- $\mathrm{Zn})$ skarn deposits, rich in base metals. Willow leaves and twigs high in cadmium (Cd) are found throughout the area. 

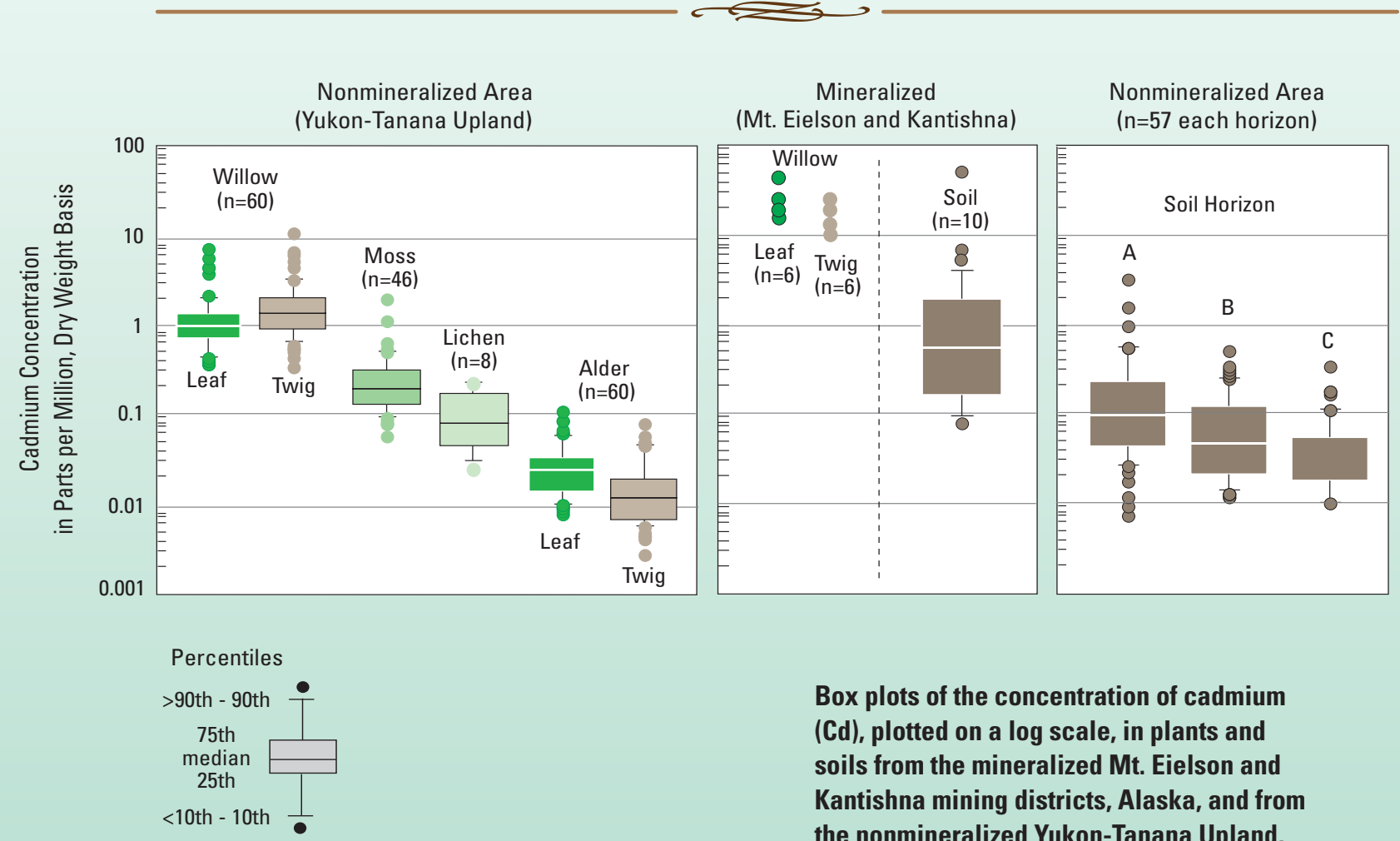

Box plots of the concentration of cadmium (Cd), plotted on a log scale, in plants and soils from the mineralized Mt. Eielson and Kantishna mining districts, Alaska, and from the nonmineralized Yukon-Tanana Upland, Alaska. In the nonmineralized area the concentration of $\mathrm{Cd}$ in various soil horizons (A horizon: topsoil, B horizon: subsoil, and C horizon: substratum or unweathered geologic material) are reported, whereas in the mineralized area $\mathrm{Cd}$ data in all three soil horizons were combined. Note that $\mathrm{Cd}$ concentrations in willow in the mineralized area are as much as $\mathbf{1 0}$ times those in the nonmineralized area. 


\title{
Differences in Retention of Selenium in Two Wetlands
}

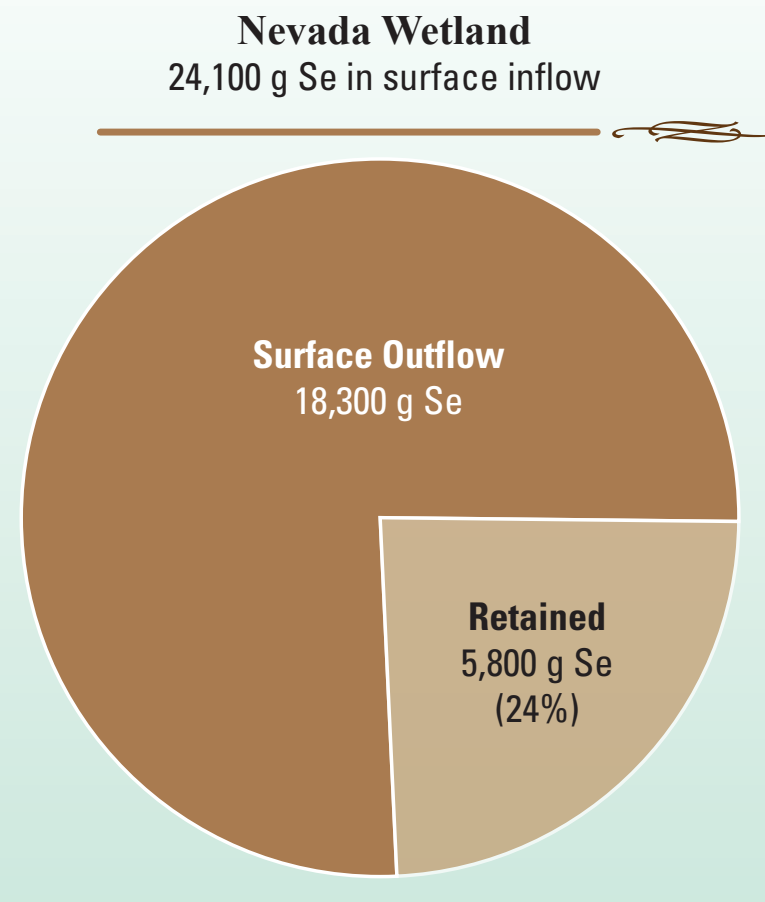

\author{
Idaho Wetland \\ $695 \mathrm{~g}$ Se in surface inflow
}

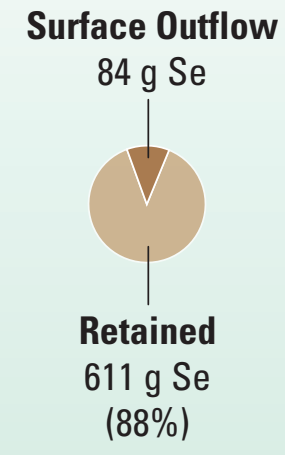

A comparison of the amount of selenium ( $\mathrm{Se}$ ) that is retained by wetlands near Las Vegas, Nevada, and in southeastern Idaho. The area of each circle is proportional to the total Se delivered to each wetland, 24,100 grams over 4 months, and 695 grams over 5 months, respectively. The Se retained in the wetland likely accumulates in wetland soils and plants.

Selenium concentrations in forage vegetation are a concern for ranchers who graze stock in mining- affected areas. These cattle browse on wetland grasses at the Idaho wetland. The standpipe is from a former mining operation.

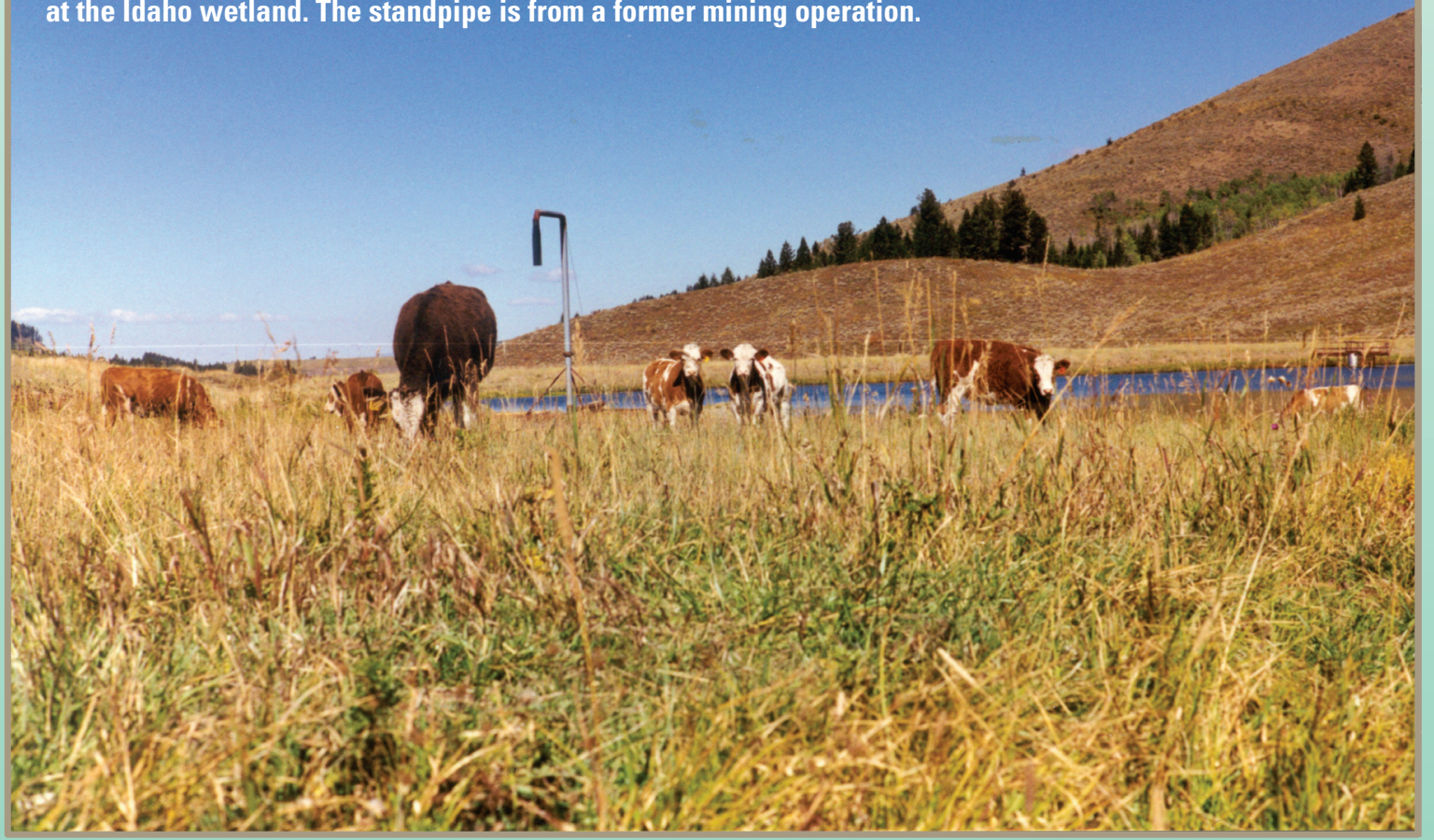




\section{Climate Influences Metal Dispersion from Arizona Mining Areas}

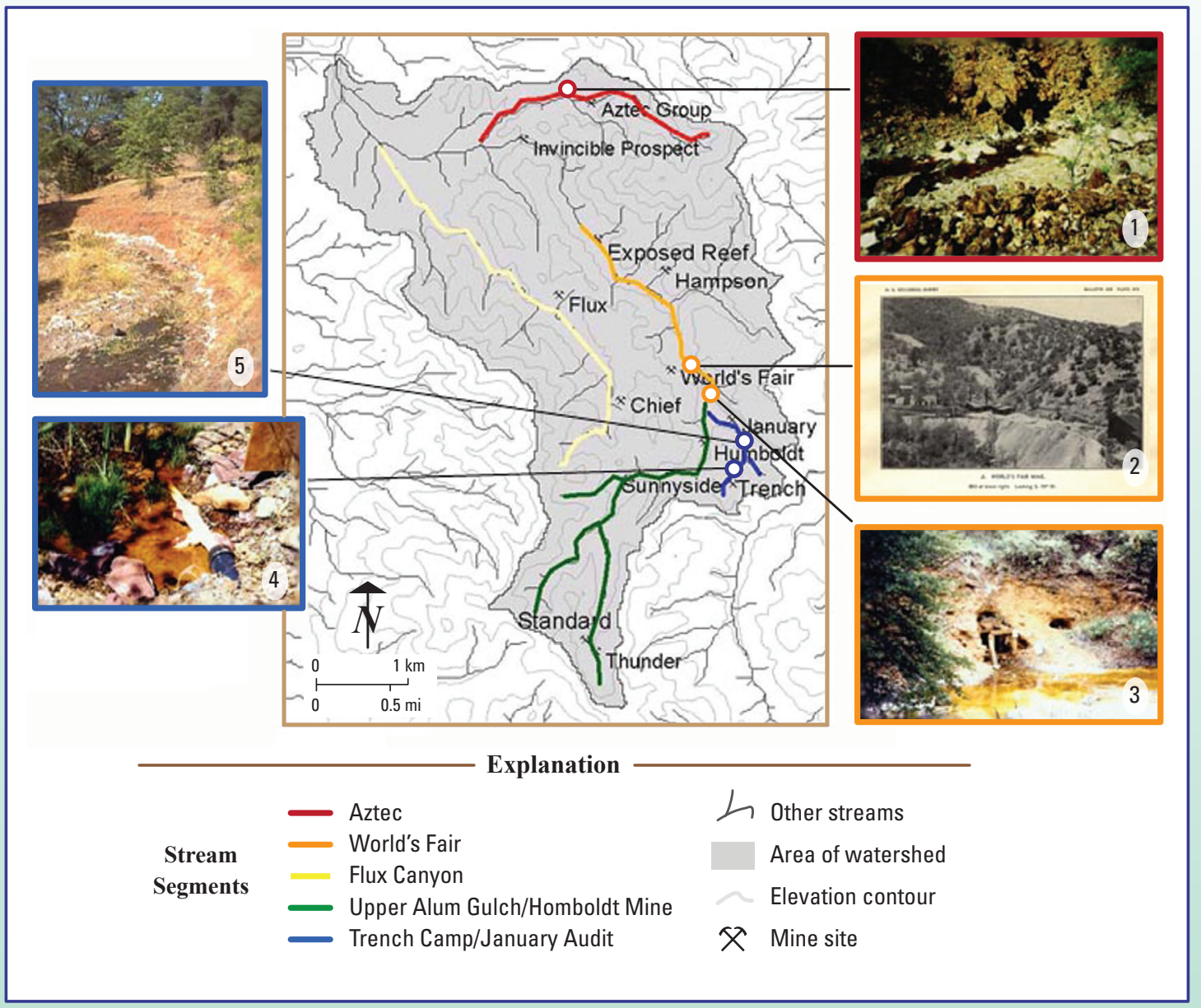

Map of the Alum Gulch-Flux Canyon watershed, Arizona, showing five defined stream "segments" and important mine sites. Segments of the same color have similar $\mathrm{pH}$ and concentrations of metals in the water; these parameters vary from 0.6 milligrams per liter of copper and pH 4.7 in Trench Camp to 3.5 milligrams per liter of copper and pH 2.9 in Upper Alum Gulch. An arid climate and low volumes of water in each stream segment during base-flow conditions (when only seepage from ground water supplies the stream) produce efflorescent metal-enriched salt deposits that can dissolve and release metals and acid during storm events.

Photo 1. Acidic, iron-rich stream water in Aztec Gulch. Stream boulders and walls are made of ferricrete, an iron-rich deposit.

Photo 2. The World's Fair Mine area circa 1908. Reproduced from Schrader, F.C., 1915, Mineral deposits of the Santa Rita and Patagonia Mountains, Arizona: U.S. Geological Survey Bulletin 582, 373 p.

Photo 3. Main portal (adit) at the World's Fair Mine. Discharge from the adit passes over a waste pile and into the adjacent stream.

Photo 4. Water in a drainage pipe from the adit at the January Mine flows into constructed wetlands that are part of the Trench Camp Mine complex.

Photo 5. White, efflorescent metal-enriched salt deposits develop as rings or in-stream crusts in the Trench Camp segment. 
This improved understanding of the metal pathways allows the land-management agencies responsible for areas affected by mining or mineralization-including the U.S. Bureau of Reclamation, U.S. Bureau of Land Management, U.S. Environmental Protection Agency, U.S. Department of Agriculture, U.S. Forest Service, and State agencies such as the Alaska Department of Fish and Game and the Arizona Environmental Quality Agency_to better plan for mitigating the impacts of chemical toxicity in sediment, water, and biota. The research results of the USGS Pathways Project have also highlighted remaining questions and pointed the way to promising avenues of further research.

\section{Acknowledgments}

The work in the USGS Pathways Project was done with the support of Kathleen Johnson, Coordinator of the USGS Mineral Resources Program, numerous colleagues in the USGS Mineral Resources Program, and our various Federal, State, and local collaborators. The manuscript benefited from the reviews of Steve Box, Tom Frost, Sue Kropschot, and Bronwen Wang, from discussions with Dave Frank, and from the technical edit by Peter Stauffer, and design and layout by Jeanne DiLeo.

\section{Sources of Additional Information}

Ashley, R.P., Rytuba, J.J., Rogers, R., Kotlyar, B.B., and Lawler, D., 2002, Preliminary report on mercury geochemistry of placer gold dredge tailings, sediments, bedrock, and waters in the Clear Creek Restoration Area, Shasta County, California: U.S. Geological Survey Open-File Report 2002-401, 47 p.
Ashton, K.L., and Duarte, O.A., 2003, Soil characterization at the World's Fair Mine site, Patagonia Mountains, Santa Cruz County, SE Arizona; implications for base metal transport during storm runoff events [abs.]: $31^{\text {st }}$ Annual GeoDaze Geoscience Symposium, GeoDaze 2003, p. 55.

Balistrieri, L.S., Box, S.E., and Tonkin, J.W., 2003, Modeling precipitation and sorption of elements during mixing of river water and porewater in the Coeur d'Alene River basin: Environmental Science \& Technology, v. 39, p. 1547-1554.

Box, S.E., Bookstrom, A.A., and Ikramuddin, M., 2005, Stream sediment geochemistry in mining-impacted streams; sediment mobilized by floods in the Coeur d'Alene-Spokane River drainage, Idaho and Washington: U.S. Geological Survey Scientific Investigations Report 2005-5011, 57 p.

Gough, L.P., Sanzolone, R.F., Lamothe, P.J., Ager, C.M., Foster, A.L., and Crock, J.G., 2003, Bioaccumulation and mobility of cadmium in willow and soils, Alaska-implications for the health of browsing animals [abs.]: U.S. Geological Survey Open-File Report 2003-097, p. 22.

Slowey, A.J., Rytuba, J. J., and Brown, G.E. Jr., 2005, Speciation of mercury and mode of transport from placer gold mine tailings: Environmental Science \& Technology, v. 39, p. 1547-1554.

Willard, P., and Stillings, L.L., 2005, A mass balance for selenium in the upper pond of the Clark County Wetlands Park, Nature Preserve, Las Vegas, NV [abs.]: Geological Society of America Abstracts with Programs, v. 37, no. 7, p. 178.

Additional information about the recently completed "Pathways of Metal Transfer from Mineralized Sources to Bioreceptors" project is at the USGS Western Mineral Resources Web site [http://minerals.usgs.gov/west/projects/ path.htm]. 